\title{
Training of pedagogical personnel for inclusive education children with disabilities
}

\author{
Irina Yakovleva ${ }^{1 *}$, Sergey Yakovlev $^{2}$, and Vera Khitryuk $^{3}$ \\ ${ }^{1}$ Moscow City University, Institute of Special Education and Psychology, Department of Special \\ Pedagogy and Complex Rehabilitation, Moscow, Russia \\ ${ }^{2}$ Institute for the Study of Childhood, Family and Education of the Russian Academy of Education, \\ Moscow, Russia \\ ${ }^{3}$ Baranovichi State University, Department of Pedagogy of the Educational Establishment, \\ Baranovichi, Brest region, Belarus
}

\begin{abstract}
With the spread of inclusive education, new requirements are imposed on a teacher, including their readiness to teach, educate, and help with the development of children with special educational needs. Scholars recognize the need to amend the training of general education teachers (primary school teachers and subject teachers) to form their readiness to teach school children with disabilities. The study presents an analysis of modern Russian research on this issue using methods of analysis, systematization, and comparison of modern approaches to teacher training for inclusive education of children with disabilities. The study reveals Russian scholars' understanding of the term "readiness for inclusive education of children with disabilities" and a list of professional and personal qualities, value-semantic guidelines, and professional competencies that an inclusive education teacher should have. Scientific approaches to the training of such a specialist (competency-based, integrated) and proposed forms of education are critically analyzed, and issues of content and new technologies used in preparing a teacher for this type of professional activity (contextual, project-based learning) are considered. The study reveals the shortcomings of the modern situation in the preparation of a general school teacher for inclusive teaching of children with disabilities, and the authors' view on changing the form of such training is proposed. As a result of the analysis, prospects for further research in the field of teacher training for inclusive education of children with disabilities are highlighted.
\end{abstract}

Keywords: teacher education, inclusive education, teacher training, teaching school children with special educational needs.

\section{Introduction}

The introduction of inclusive education into modern school practice is one of the leading trends in educational policy in different countries. An increasing number of children with

\footnotetext{
${ }^{*}$ Corresponding author: yakovlevaim@mgpu.ru
} 
special educational needs are enrolled in general education schools at their place of residence and their teaching requires appropriate preparedness from teachers.

Modern teachers have little knowledge of technologies that ensure the quality of the development of educational programs by students with disabilities and experience a lack of knowledge in the field of formation of an inclusive culture. Reasons for this are insufficient scientific and methodological support, lack of staff for psychological and pedagogical support of children with disabilities, as well as unpreparedness of the administration, teachers, and educators to interact with children with disabilities [1-3].

There is a need for changes in teacher training for general education schools since quality inclusive education can only be provided by a teacher prepared for this process. This position is supported by many Russian and foreign researchers [1, 4-6].

In education, there are different models of teacher preparation for work in an inclusive school: teachers take one or more training courses [7,8] or practices in special schools to provide teachers with an opportunity to get acquainted with students with different learning needs [9]. These internships allow teachers to view all children as learning-capable before training [10].

In universities, to form a professional attitude of future teachers to the inclusion of children with special educational needs in the educational process, volunteer activities, participation in programs of public organizations, and other events that involve interaction with people with developmental disabilities are used $[11,12]$.

\section{Methods}

For the study, we selected scientific works of Russian scholars carried out in the field of training teachers for inclusive education over the past ten years. During the analysis, the task was to determine authors' understanding of the concept of "readiness for inclusive education" and scientific approaches to training a teacher of inclusive education, systematize forms and technologies they offer to prepare teachers for inclusive education, and show trends observed.

\section{Results and discussion}

The analysis of the studies showed that Russian scholars consider the need to prepare children with special educational needs for inclusive education as teachers of a general education school [2, 6, 13-16], as well as special educators and psychologists [1, 3, 17].

The term "a teacher's readiness for inclusive education" is understood unambiguously. Authors agree that this concept includes personal and activity components [1-3, 14, 15].

Professional and personal readiness of a teacher of inclusive education lies in their mastery of the system of professional values (recognition of the value of a person's personality, regardless of the severity of their disability, focus on obtaining not only educational results but mastering skills necessary for an independent life, creative nature of the pedagogical activity, etc.), as well as in the formation of significant professional and personal qualities such as mercy, empathy, tolerance, and high level of subjective control. The activity component includes the main types of pedagogical activities, which have their specifics when it comes to children with special educational needs.

The most common model for preparing teachers for inclusive education is through continuing education courses.

N.M. Nazarova [1] developed a structural and functional model for advanced training and retraining of teachers of educational institutions for work in the conditions of inclusion which contains several levels. The first level is intended for teachers and psychologists who assist infants and young children; the second level is for teachers who work with children of 
preschool and primary school age; the third level is for teachers who work with school-age children; the fourth level is for teachers teaching people with disabilities in the vocational education system. For each of the levels, professional competencies of a teacher in the field of educational, correctional, developmental, diagnostic, analytical, advisory, organizational, social, pedagogical, psychoprophylactic, cultural, and educational activities are determined.

T.A. Solovieva points to the advisability of combining full-time and distance learning, which allows teachers, without interrupting their main activities, to improve their professional competence. At the same time, a combination of these forms allows for maximum consideration of the individual needs of teachers [2]. For this purpose, she suggested using electronic educational resources, which contain guidelines, document templates, software products, and other materials necessary for organizing activities of inclusive education organizations.

In our opinion, the issue of assessing the effectiveness of teacher training for inclusive education, including in refresher courses, has not been reflected in modern studies. As a rule, teachers listen to lectures on the developmental features of children with various disabilities and receive information about the technologies of their teaching, but are not able to practically apply them, and knowledge they gain is often not used. Training should be as individualized as possible. That is, a teacher, who has a child with a developmental disorder in the class, should be able to undergo training online according to a program that will acquaint exactly with the information that relates to a specific disability. Such a teacher should be assigned to an internship with an experienced specialist who will be able to assess how ready the trainee is to work with a child with disabilities.

For universities, a model has been developed for preparing a teacher to work with children with disabilities [3]. At the same time, S.V. Yakovlev proposed and proved the effectiveness of the use of technologies aimed at developing the value-semantic sphere of the individual, professional, and personal development of a tutor and the formation of professional competencies and readiness of teachers for innovative activities [18, 19].

The study discusses the content of training future teachers of general education for inclusive education. Bachelor's and master's programs in the areas of "Pedagogical Education" and "Psychological and Pedagogical Education" include special courses aimed at preparing students for the inclusive education of children with disabilities; internships are organized in inclusive schools. For example, courses such as "Special and inclusive education of children with disabilities" [1] and "Technology for the development of an adapted basic educational program" [2] are proposed for introduction in the undergraduate program. However, in general, teacher training for inclusive education has not changed significantly: new courses have appeared, but their content does not integrate with the main disciplines of specialized training [16, 20]. For example, math classes do not include the study of techniques that allow explaining mathematical material to children with mental retardation. This problem is also pointed out by Kathryn S. Young [4].

Some studies attempt to link specialized training with the practice of inclusive education but are mainly aimed at developing a student's motivation to work with children with disabilities and reflect on their activities and are not concentrated on the content side of training [13].

T.A. Solovieva [2], considers the necessity of the focus of master's programs on the formation of new competencies in teachers. For example, the content of the master's program "Designing adapted educational programs" is substantiated.

An interesting model of joint training of future teachers of general education (primary school teachers) and special psychologists to work with children with mental retardation in an inclusive education was proposed by M.A. Akopian, Iu.A. Afonkina, and T.V. Kuzmicheva [14]. The choice of such a model is justified by the fact that since in the conditions of inclusive education, the teamwork of specialists and teachers is necessary, then 
it is necessary to prepare for it, starting with studying at university. A monograph presents the content and forms of work aimed at preparing students for productive interaction in an interdisciplinary team of specialists supporting a child with mental retardation [14]. For example, a new form of organization of practice has been tested - small school councils, in which students, future primary school teachers and future special teachers, work in a unified team.

The authors identified new professional competencies that teachers of general education and special psychologists must possess to carry out effective activities in the conditions of inclusion. A technology was developed aimed at training future primary school teachers and special psychologists in orderly interaction in the process of studying the individual development of primary school children with mental retardation.

Studies also examined the issues of training special teachers and psychologists for the implementation of inclusive education for children with disabilities. E.V. Zvoleyko suggests using contextual and project-based learning technologies [17]. She proposed a seminar on solving professional problems that meets requirements of practice-oriented education.

\section{Conclusion}

Thus, issues of preparing a teacher for inclusive education of children with disabilities are considered in most studies from the standpoint of a competency-based approach: a list of teacher's competencies has been determined.

During the study, special attention was paid to the development of the personal and semantic sphere and the professional and personal qualities of future teachers of inclusive education. Furthermore, teaching models are proposed aimed at the formation of teamwork skills, which is necessary for the organization of the psychological and pedagogical support of a child with disabilities. Several studies reflect the design of the content of bachelor's and master's programs.

Prospects for further research are in the integration of the content of general pedagogical education with preparation for working with children with disabilities, the development of criteria for assessing the professional competence of a teacher of inclusive education, as well as development of new training models that will improve the quality of inclusive processes in education.

\section{References}

1. N.M. Nazarova, Fenomenologiia sovmestnogo obucheniia: integratsiia i inkliuziia [Phenomenology of Collaborative Learning: Integration and Inclusion] (Pero, Moscow, 2018)

2. T.A. Solovieva, Sistemnyi podkhod k organizatsii protsessa vkliucheniia mladshikh shkolnikov s ogranichennymi vozmozhnostiami zdorovia v obshcheobrazovatelnuiu sredu [Systematic Approach to Organizing the Process of Including Younger School children with Disabilities in the General Educational Environment] (Moscow State Pedagogical University, Moscow, 2018)

3. I.M. Yakovleva, Regional Education: Modern Trends, 3(39), 126-130 (2019)

4. S.Y. Kathryn, Teaching and Teacher Education, 27(2), 483-493 (2011). https://doi.org/10.1016/j.tate.2010.10.001

5. T. Lorman, Teacher education for inclusion (Routledge, London, 2010)

6. L.M. Kobrina, Pedagogy, 4, 118-120 (2016) 
7. K. Tait, N. Purdie, International Journal of Disability, Development and Education, 47(1), 25-38 (2000)

8. J. Lancaster, A. Bain, International Journal of Disability. Development \& Education, 54(2), 245-256 (2007). https://doi.org/10.1080/10349120701330610

9. E. Walton, L. Rusznyak, Teaching and Teacher Education, 36, 112-120 (2013). https://doi.org/10.1016/j.tate.2013.07.011

10. T.J. Burant, D. Kirby, Teaching and Teacher Education, 18(5), 561-575 (2002). https://doi.org/10.1016/S0742-051X(02)00016-1

11. E. Avramidis, P. Bayliss, R. Burden, Teaching and Teacher Education, 16(3), 277-293 (2000). https://doi.org/10.1016/S0742-051X(99)00062-1

12. C. Forlin, D.J. Chambers, Asia-Pacific Journal of teacher education, 39(1), 17-32 (2011). https://doi.org/10.1080/1359866X.2010.540850

13. E.V. Ketrish, Gotovnost pedagoga k rabote v usloviiakh inkliuzivnogo obrazovaniia [Teacher's Readiness to Work in Inclusive Education: Monograph] (Publishing House of the Russian State Vocational Pedagogical University, Ekaterinburg, 2018)

14. M.A. Akopian, Yu.A. Afonkina, T.V. Kuzmicheva et al., Teoriia i praktika inkliuzivnogo obrazovaniia v Rossii i za rubezhom: Monografiia [Theory and Practice of Inclusive Education in Russia and Abroad: Monograph] (Limited Liability Company International Research Center "Scientific Cooperation", Rostov-on-Don, 2016)

15. G.V. Akhmetzhanova, A.A. Stepanko, Baltic Humanitarian Journal, 7(1(22)), 181-184 (2018)

16. O.S. Kuzmina, The Newman in Foreign Policy, 37(81), 49-51 (2017)

17. E.V. Zvoleyko, 20 let professionalnoi podgotovke spetsialnykh psikhologov $v$ Zabaikale [20 years of Professional Training of Special Psychologists in Transbaikalia], in Pedagogical Education: History, Traditions and Prospects. Collection of Articles of the All-Russian Scientific-practical Conference Dedicated to the $80^{\text {th }}$ Anniversary of Higher Pedagogical Education in Zabaykalsky Krai, 26 October 2018, Chita, Russia (2019)

18. S.V. Yakovlev, Tiutor i vospitannik: pedagogicheskoe vzaimodeistvie sistem tsennostei: Monografiia [Tutor and Studentl: Pedagogical Interaction of Value Systems: Monograph] (INFRA-M, Moscow, 2017)

19. S.V. Yakovlev, Vospitanie tsennostnykh osnovanii lichnosti [Education of the Value Foundations of the Individual] (INFRA-M, Moscow, 2017)

20. A.M. Bazavodova, E.M. Bazavodova, N.V. Tarasenko, A.N. Tiulegenova, Gotovnost studentov $k$ budushchei professionalnoi deiatelnosti v inkliuzivnom obrazovanii [Readiness of Students for Future Professional Activities in Inclusive Education], in Inclusive Education: Theory and Practice. Collection of Materials of the IV International Scientific and Practical Conference "Inclusive Education: Theory and Practice", 14 June 2019, Orehovo-Zuyevo, Russia (2019) 